\title{
Geoelectrical Sounding for The Determination Of Groundwater Prospects In Awgu And Its Environs, Enugu State, Southeastern Nigeria
}

\author{
OKEKE J. P. ${ }^{1}$; EZEH C. C ${ }^{2}$; OKONKWO A. C. \\ 1,2,3(Department of Geology and Mining, Enugu state University of science and Technology, Enugu State, \\ Nigeria. West Africa). \\ Johnslash2000@yahoo.co.uk
}

\begin{abstract}
Geoelectrical sounding to determine the groundwater prospect in Awgu and its environs has been carried out. The study area lies within longitudes $007^{0} 25^{\prime} \mathrm{E}$ and $007^{\circ} 35^{\prime} \mathrm{E}$ and latitudes $06^{\circ} 02^{\prime} \mathrm{N}$ and $06^{\circ} 17^{\prime} \mathrm{N}$ with an area extent of $513 \mathrm{sqkm}$. The area is underlain by two lithostratigraphic units, Awgu Shale and Owelli Sandstone. A total of ninety five (95) Vertical Electrical Soundings (VES) was acquired employing the Schlumberger electrode array configuration, with a maximum electrode separation ranging from $700 \mathrm{~m}$ to $800 \mathrm{~m}$. Data analysis was done using a computer program RESOUND to generate the layer apparent resistivity, thickness and depth. A maximum of eight (8) layer resistivity were generated in each sounding point with a depth range of $50 \mathrm{~m}$ to $356 \mathrm{~m}$. From the interpreted VES data layer 6,7 , and 8 are possible target for prospective aquifer horizons. Interpreted geoelectric layers show a sequence of shale/sand - shale sand - sand. Various contour maps were constructed using surfer 10 contouring program- Iso resistivity, Isochore (depth), Isopach (thickness), Longitudinal conductance and transverse resistance to show variation of parameters in the study area. The frequency distribution of the VES curve types were plotted using the excel tool kit. The QQH curve type predominates. Groundwater potential zone map and flow direction maps were also plotted to show the groundwater distribution pattern in the study area. Three groundwater prospective zones were delineated. Deeper prospects zones cover $50 \%$ of the study area, with an average depth of $120 \mathrm{~m}$. Zones of shallow prospects covers $20 \%$ of the study area, with an average depth of $65 \mathrm{~m}$ while No prospects zones covers $30 \%$ of the study area.
\end{abstract}

Keyword: Geoelectric sounding, transverse resistance, Longitudinal Conductance, Groundwater Potential zones, Groundwater flow directions.

\section{INTRODUCTION}

Awgu and its environs are highly problematic in terms of groundwater. Following the increasing population in the area, there is need to explore for groundwater in other to meet the water requirements. To achieve this, we must have a reliable estimate of groundwater potential and this is possible by a systematic exploration program using modern scientific tools. Geophysical approach has among others, met this need because a wide range of the approaches has been used with varying degree of success in providing useful information about the aquifer (Sundararajan, et al, 2007). The use of geophysical methods provides valuable information with respect to distribution, thickness and depth of groundwater bearing formations. Various surface geophysical techniques are available but Electrical Resistivity Method has been used because of its relatively high diagnostic values. Abortive wells abound in the study area as most water wells are not functioning. Groundwater aquifer data largely do not exist in the area. Hence, delineating the groundwater zones will provide a better picture of the underground water exploration pattern.

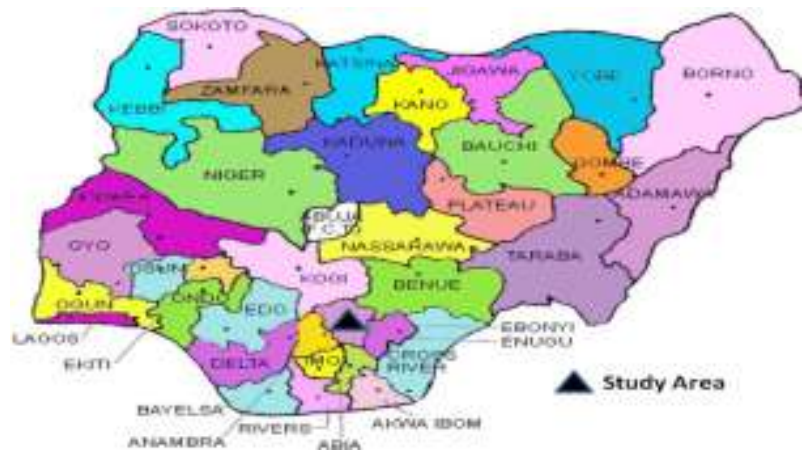

Figure 1. Map of Enugu State showing the location of the study area. 


\section{LOCATION AND ACCESSIBLITY}

The study area lies within longitudes $007^{0} 25^{\prime} \mathrm{E}$ and $007^{0} 35^{\prime} \mathrm{E}$ and latitudes $06^{0} 17^{\prime} \mathrm{N}$ and $06^{\circ} 02^{\prime} \mathrm{N}$ with an area extent of 513sqkm (Figure 1 and 2). The study area covers parts of Aninri and Nkanu West.

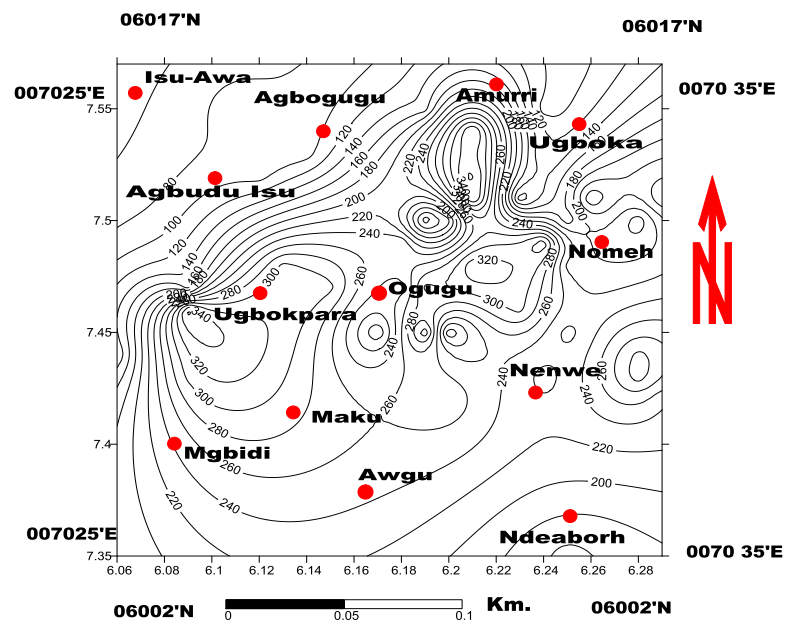

Figure 2: map of the study area

The major towns in these areas include: Ugboka, Amurri, Ndeaboh, Nenwe, Awgu, Mgbowo, Onoli, Mmaku, Ogugu, Owelli, Ihe, Agbogugu, Isu-Awaa among others. These areas are accessed by major and minor roads as well as track roads and footpaths that are interconnected. It is mainly accessed by the Enugu- Port Harcourt old road linking these towns.

\section{PHYSIOGRAPHY}

The study area consists of irregular topography. The eastern part of the study area is made up of highlands while the western part is fairly lowlands. (Figure 3). The highland areas include towns like: Ngene Ugbo, Amolie, Obeagu, Mmaku with Ugbokpala community as the highest in the area, with an elevation of 333 meters above sea level (ASL).

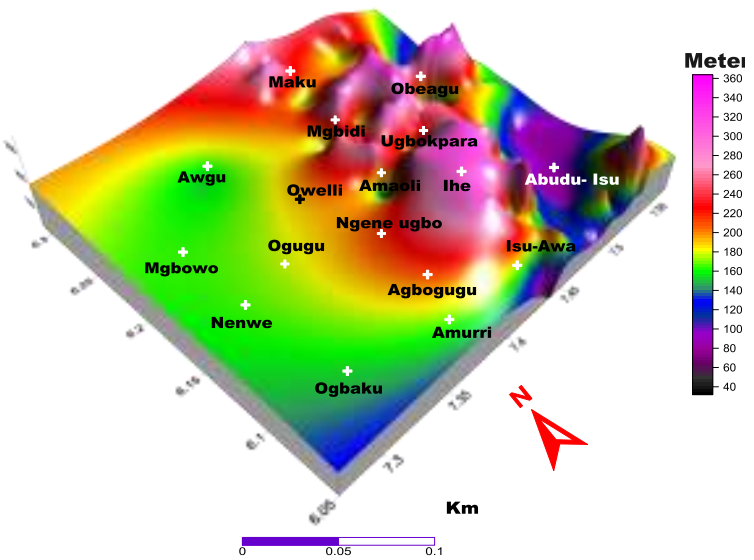

Figure 3: Surface map showing study area

The lowland areas include communities like Owelli, Awgu, Nenwe, Ndeaboh etc. The lowest part of the area is at Ndeaboh with an elevation of $53 \mathrm{~m}$ ASL. Some of the activities in these areas are rice farming as a result of stagnant water especially, in parts of Ndeaboh, Mgbowo and Nenwe. The area is sparsely Vegetative.

\section{GEOLOGY}

The study area lies on the geologic formation referred to as Awgu-Ndiagboh formation and Agbani Sandstone is its lateral equivalent. The formation is within the southern portion of the Benue Trough of Nigeria. It has two Lithostrategraphic units characterized by sequence of shale and sand (Figure 4). It is well-bedded, Awgu Shale (Coniacian age) Owelli Sandstone (Campanian age) with a regional Dip of about 180. The Awgu Shale is underlain by the Eze-Aku shale conformably and is between Awgu and Ndeaboh in Southeastern Nigeria. 


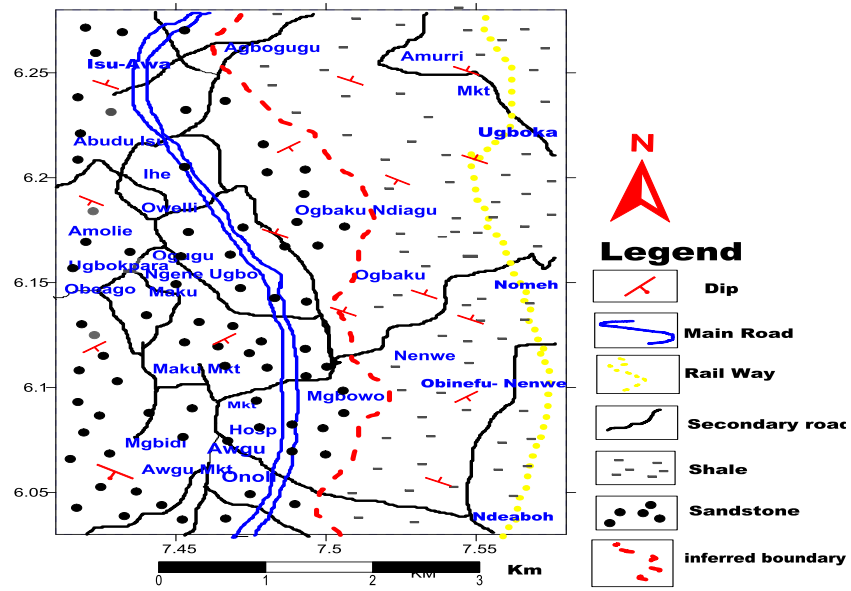

Figure 4. Geologic map of the study area

The lithology is bluish-grey well-bedded shale inter-bedded with fine yellow calcareous sandstone and shaly limestone with a total thickness of $900 \mathrm{~m}$.

\section{HYDROGEOLOGY}

The study area Awgu falls within the Anambra Basin, located to the southern part of Enugu metropolis. More than $90 \%$ of the area is underlain by Cretaceous rocks of the Asu River, Eze-Aku, Awgu, Nkporo and Mamu Formations, with the oldest, the Asu River Formation rocks. Awgu Ndeaboh Formation is generally shale and clays with thickness of about 900meters. The groundwater potential is not encouraging (Ezeh, 2012) as shale does not readily give out its water content. Aneke (2007) proposed an exploration strategy for exploiting the groundwater from the fractured shaley units, which are the main water bearing units in the study area. Groundwater is mainly found in the overburden and zone of cracks restricted shallow depth and fractured shale from deeper probe.

\section{THEORY AND METHOD}

The apparent resistivity $(\rho)$ function of current passed into the ground, measured by potential electrodes as potential difference (Voltage) is given as interpreted (Figure 5)

$$
p a=\pi \times \frac{V}{I} \times\left[\frac{\left(\frac{A B}{2}\right)^{2}-\left(\frac{M N}{2}\right)^{2}}{M N}\right]
$$

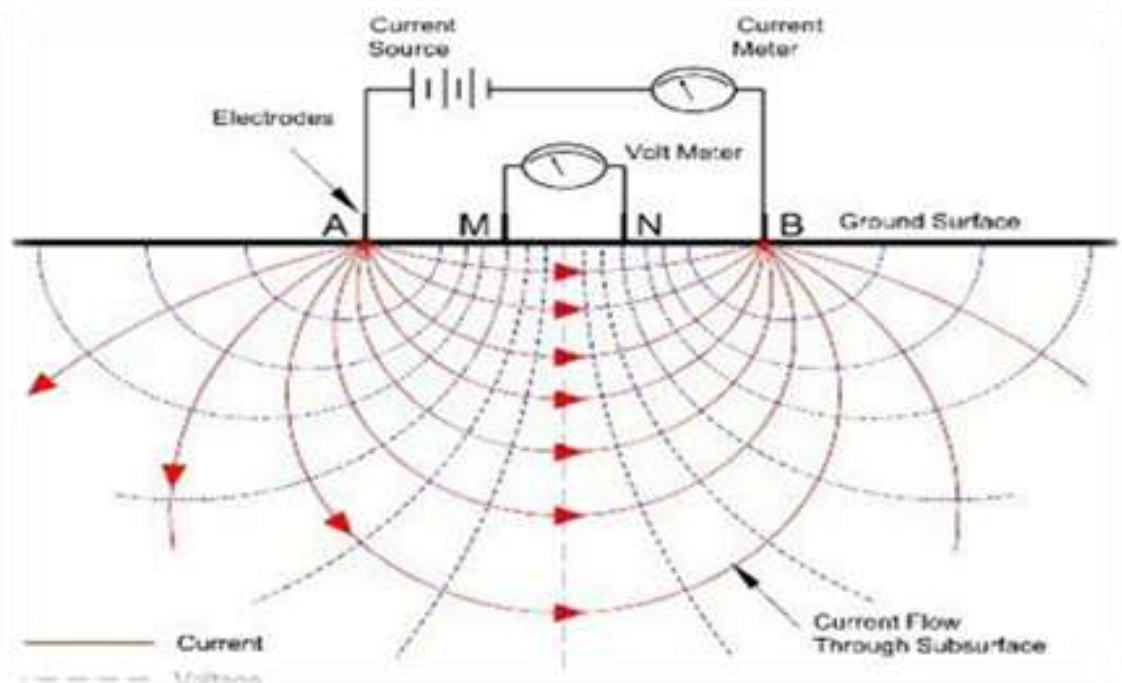

Figure 5 Current flow patterns 
Where $\mathrm{R}$ is the resistance, $\mathrm{AB}$ and $\mathrm{MN}$ are current and potential electrodes respectively (Paranis, 1986). A multilayer resistivity model consists of layer apparent resistivity, thickness and depth. Further derivatives are convolved to generate the Geoelectric parameters. These show electric boundaries separating layers of different resistivities (Zohdy, et al., 1990). A Geoelectric layer is described by two fundamental parameters: its layer apparent resistivity $(\rho$ a) and its thickness (h). The Geoelectric parameters are derived based on apparent resistivity and thickness include:

Longitudinal conductance (S)

$\mathrm{S}=\frac{h}{\rho \mathrm{a}}$

Transverse resistance $(\mathrm{T})$

$\mathrm{T}=\mathrm{h} . \rho \mathrm{a}$.

The parameters T and S were named the "Dar - Zarrouk parameters "by Maillet (1947). Correlative resistivities of $\mathrm{T}$ and $\mathrm{S}$ are given below

Longitudinal resistivity $(\rho \mathrm{L})$

$\mathrm{PL}=\mathrm{h} / \mathrm{S}$

Transverse resistivity $(\rho \mathrm{T})$

$\rho \mathrm{T}=\mathrm{T} / \mathrm{h}$

Substituting equation (2) into equation (4), and equation (3) into equation (5) it appears that apparent resistivity equals longitudinal resistivity and transverse resistivity.

$\rho \mathbf{a}=\rho \mathbf{L}=\rho \mathbf{T}$

Therefore, if apparent resistivity values can be used to infer subsurface lithology, then stacked longitudinal resistivity and transverse resistance can be used to investigate the lateral extent of subsurface lithology

(Okonkwo, et al, 2014)

\section{DATA ACQUIZITION}

Ninety five (95) vertical electrical soundings (VES) were acquired within the study area (Figure 6). Some were stationed very close to existing boreholes, for correlation purposes. The Schlumberger electrode configuration was used with maximum current electrode separation $\mathrm{AB}$, ranging from $700 \mathrm{~m}$ to $800 \mathrm{~m}$ depending on the accessibility of the road.

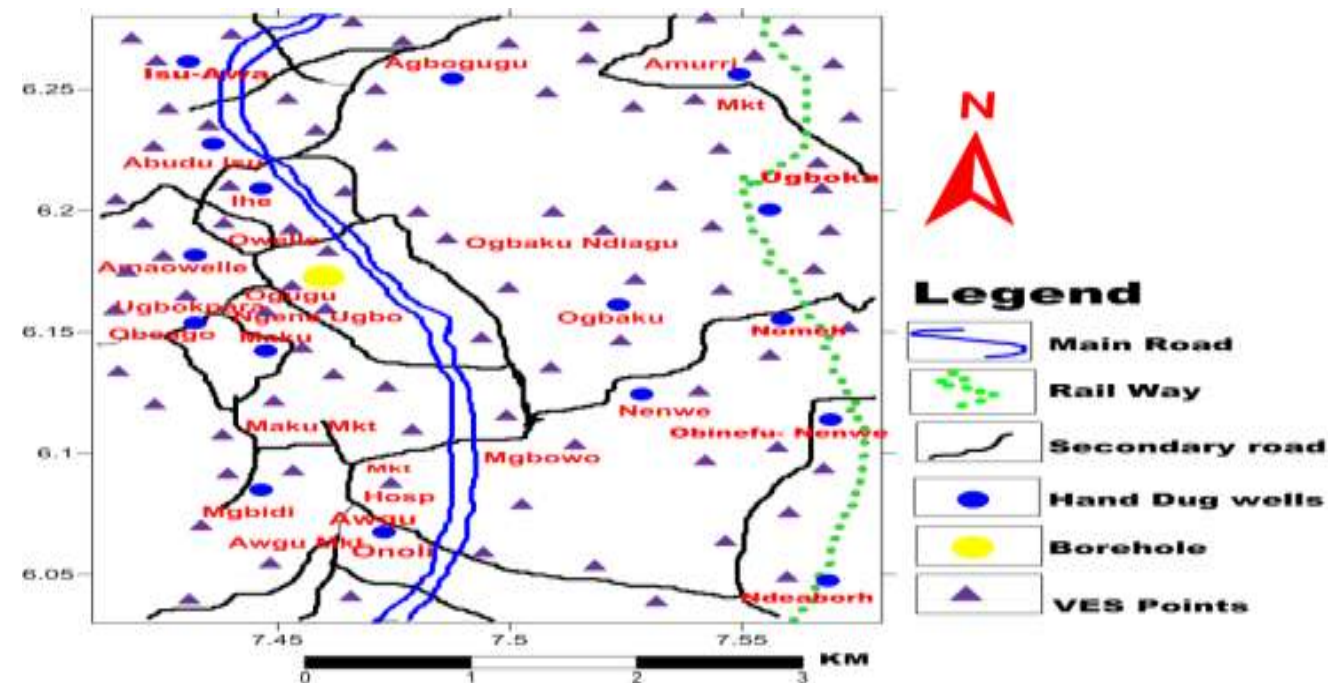

Figure: 6: Showing the VES Points, Hand-dug wells and Borehole

After acquiring the data, the measured field resistance $(\mathrm{R})$ in ohms was converted to apparent resistivity $\left(\rho_{\mathrm{a}}\right)$ in ohm-meter by multiplying resistance $(\mathrm{R})$ by the geometric factor $(\mathrm{K})$. A log-log graph plot of apparent resistivity $\left(\rho_{a}\right)$ against current electrode distance $(\mathrm{AB} / 2)$ was plotted for each VES station to generate a sounding curve. Using the conventional partial curve matching technique, in conjunction with auxiliary point diagrams (Orellana and Mooney, 1966; Koefoed, 1979; Kellar and Frischknecht, 1966), layer resistivities and thickness were obtained and the results were presented as frequency distribution chart (Figure 7), geoelectric sections and maps. Table 1 shows the summary of the VES results in terms of the geoelectric properties of the study area. These parameters were used to prepare geoelectric sections and subsurface maps such as Isoresistivity, Isopach, Isochore, longitudinal conductance and transverse resistance maps. 


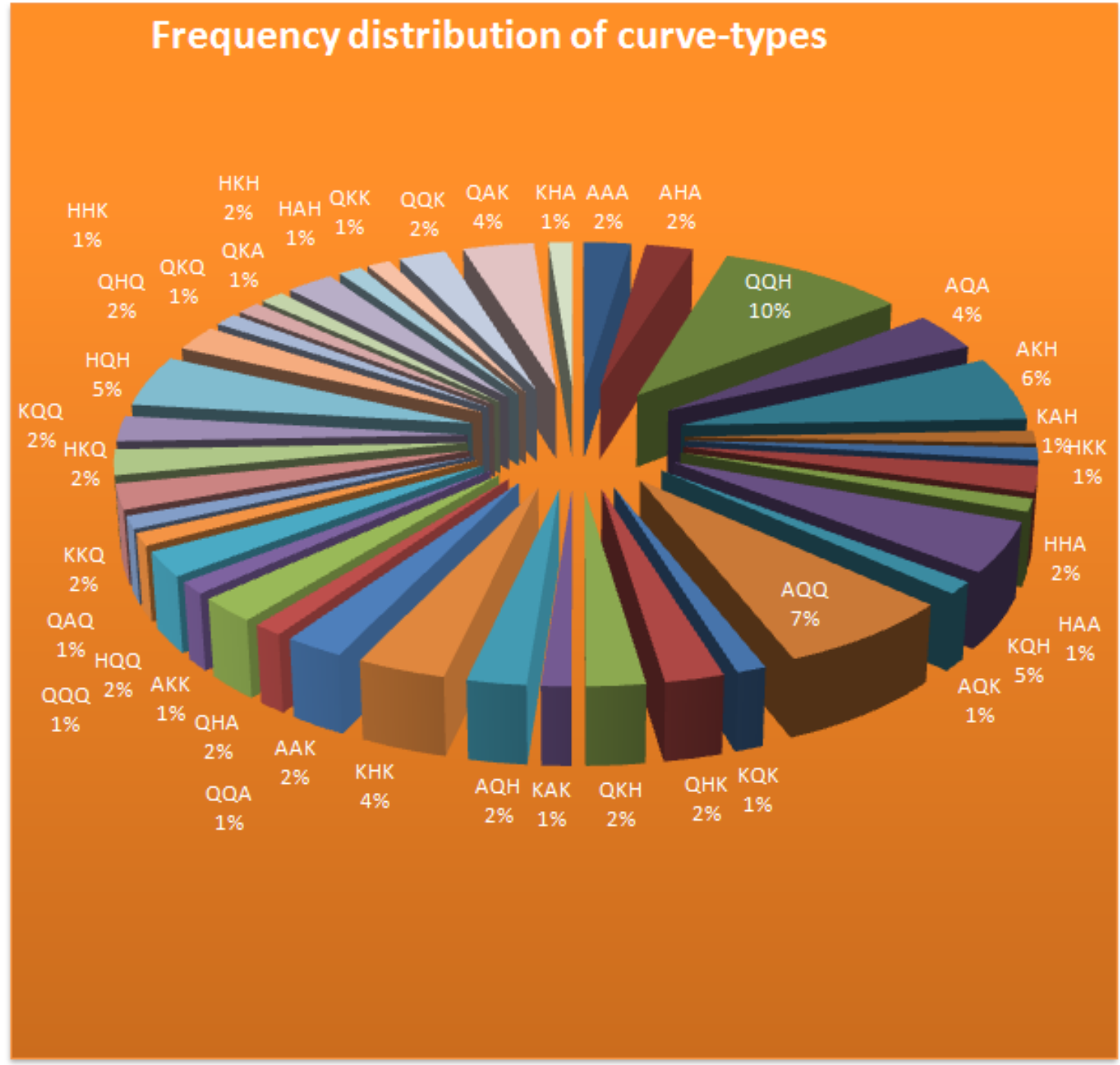

Figure 7: Frequency distribution of the curve types

\section{DATA INTERPRETATION}

The interpretation was done using the curve types, the resistivity values of the geoelectric units, the thicknesses, Dar-Zarrouk parameters (Maillet, 1947) and its analysis (Niwas and Singhal 1981) surface maps and regional geology of the study area.

The resistivity curve types associated with the study area from VES 1-95 include among others: QQH, AQA, AKH, HKK, HHA, KQH, AQQ, QKH, QHQ, QKK, and QQK (Table 1). H-type curve, account for 25\%, indicating fractured shale horizon K-type curve account for $20 \%$ and A type-curve account for $21 \%$. Approximately $4 \%$ of the soundings are 8-layered curve type, while about $40 \%$ are 7 -layered, $45 \%$ are 6 layered, $7 \%$ are 5 layered, $2 \%$ are 4 layered and $2 \% 3$ layered.

\section{RESULTS AND DISCUSSION}

Contour maps of the apparent resistivity, the Isopach, the depth, the longitudinal conductance, the transverse resistance, groundwater potential and flow direction maps of the aquiferous horizons have been constructed using the results of the resistivity sounding interpretation. For layer 6 , high resistivity range of 800 to 1400 was indicated around the south, Onoli; East, Ogbaku and Nomeh, Ngeneugbo, Mgbidi, Obeagu with thickness range of 15 to 30 extending to depth of $60 \mathrm{~m}$ to $140 \mathrm{~m}$ (Figure 8a, 8b, 8c)). 


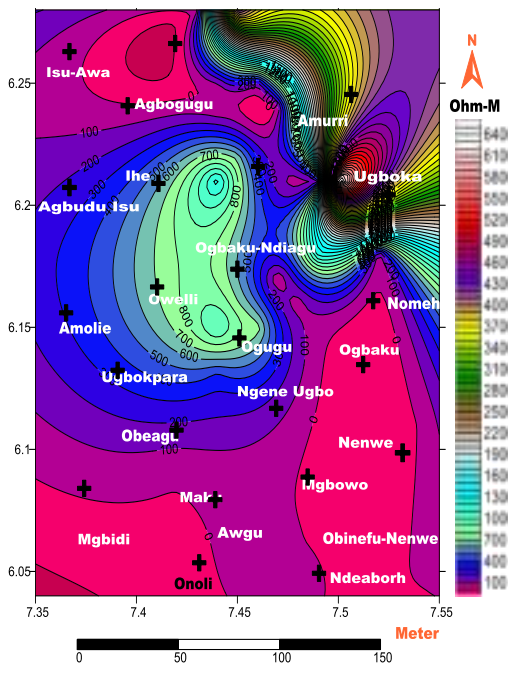

(a)

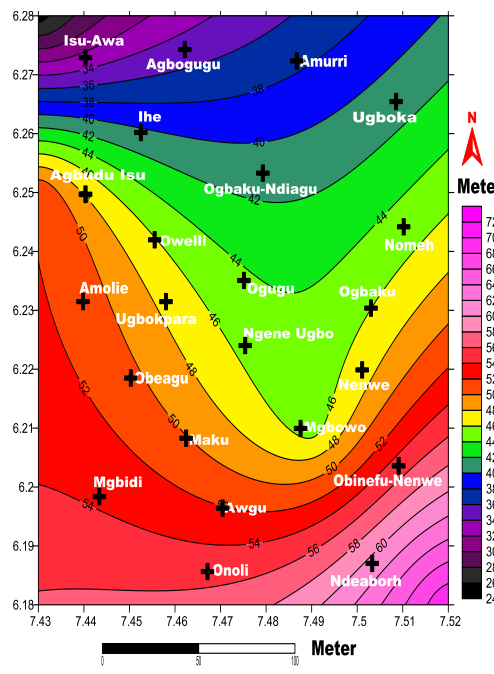

(b)

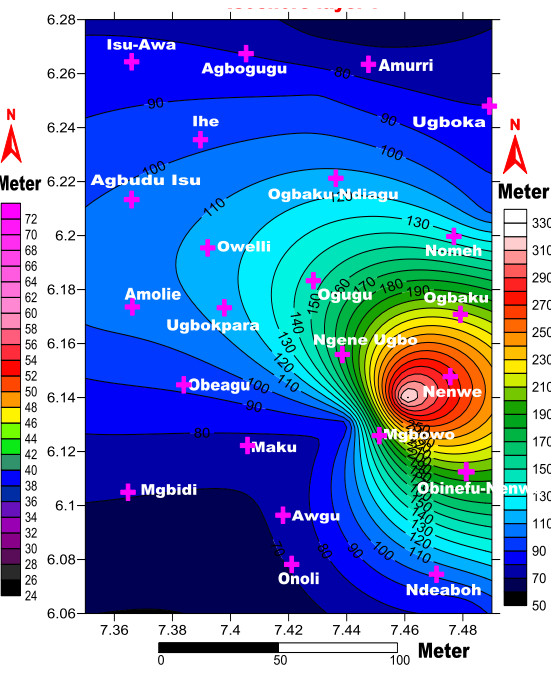

(c)

Figure 8: Countour Maps of Layers 6 showing (a)Iso resistivity, (b) Isopach, (c) Isochore

Low resistivity observed at Ndeaboh and Mgbowo among others which indicate argillaceous rocks, which are possible shale/clay.
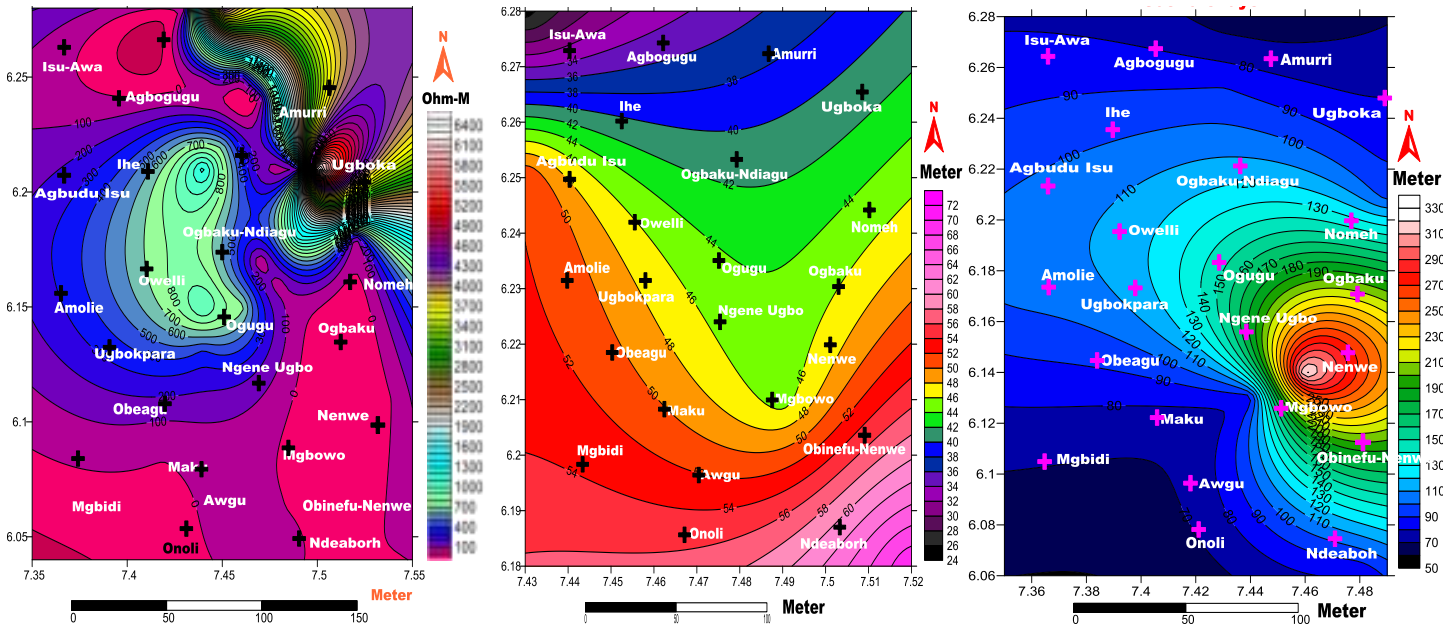

Figure 9: Countour Maps of Layers 7 showing (a)Iso resistivity, (b) Isopach, (c) Isochore

For layer 7 , high resistivity range of $1000 \mathrm{ohm}-\mathrm{m}$ to $5000 \mathrm{ohm}-\mathrm{m}$ observed almost the whole area (Figure 9a) thickness range of $32 \mathrm{~m}$ to $60 \mathrm{~m}$ (Figure 9b) and a depth range of $80 \mathrm{~m}$ to $200 \mathrm{~m}$ (Figure $9 \mathrm{c}$ ) this is an evidence deep prospect. The distribution of the aquifer transverse resistance and longitudinal conductance of layers 6 and 7 are computed from the VES interpretation as shown in Figures (10a, 10b) and Figure (11a, 11b) respectively.
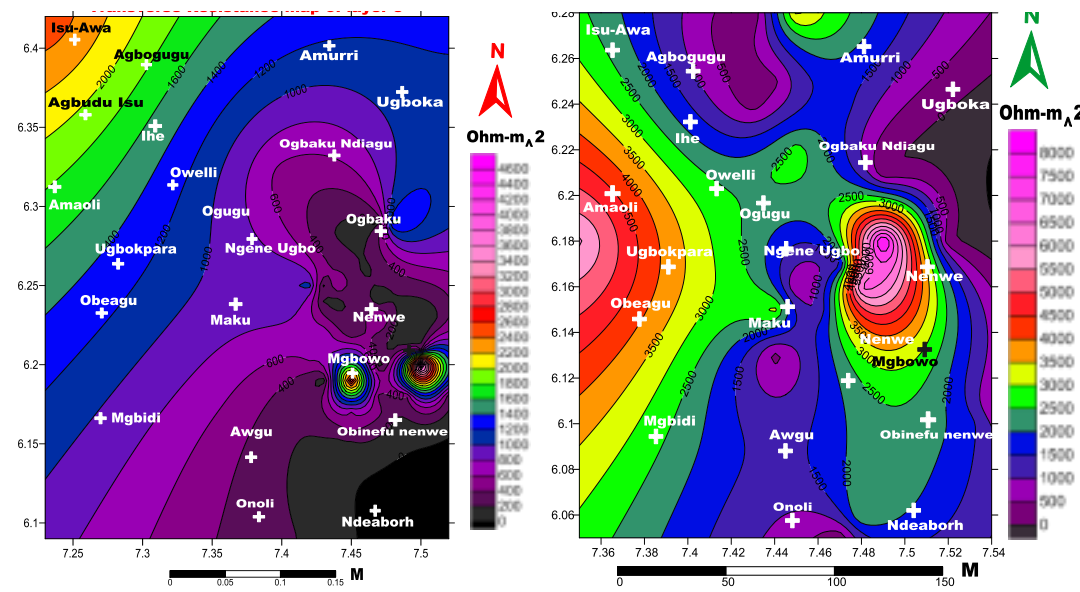

Figure10: Countour Maps of Transverse resistance (a) Layer 5, (b) Layer 6 

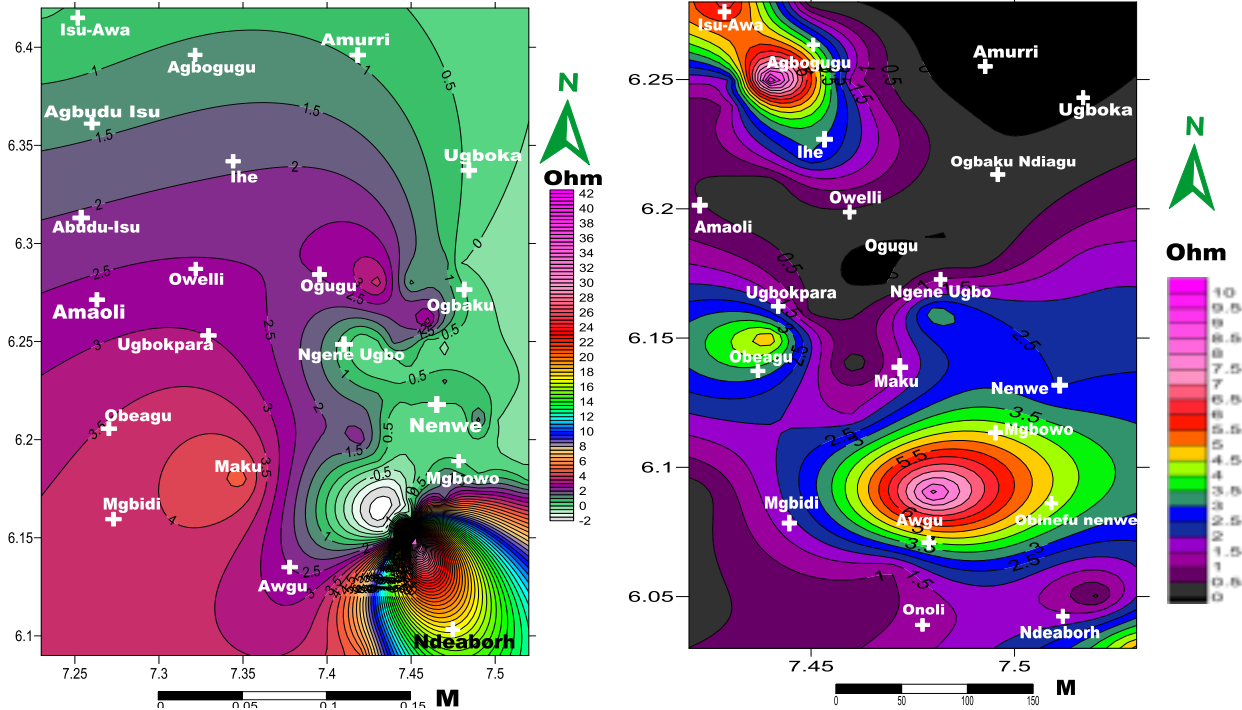

Figure11: Countour Maps of Longitudinal conductance (a) Layer 5, (b) Layer

\section{GROUNDWATER POTENTIAL ZONES}

Groundwater potential distributions in the study area are indicated by green color (deeper prospect) towns in that area includes Ugboka at the northeast, Owelli, Ogugu, Ugbokpara, Ndeaborh amongst others. Yellow color (shallow prospect) towns in that area includes Ogbaku, Awgu and red (no prospect) are places like Mgbidi. Nnewe, Isu Awa( Figure 12a)

\section{GROUNDWATER FLOW DIRECTIONS}

The ground water flow pattern in the study area is with a major divide along the east - west axis of the area. The flow directions are towards the Northeast, South and Southwest. The major flow pattern is to the North East, south, South East. There is also a convergence of flow around Ogugu-Ngeneugbo-Owelli indications of possibility of high yield. Water divide has a negative impact on the ground water resources because where they occur, there is low prospect. (Figure 12b)

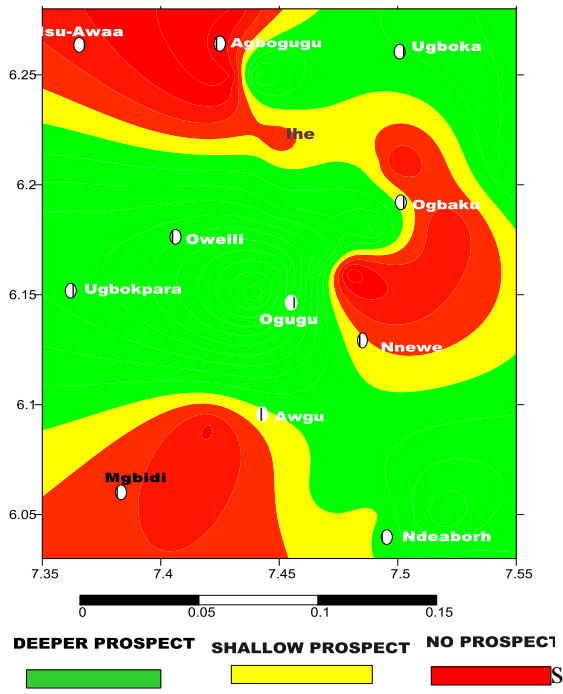

(a)

Fugure 12: (a) Map of Groundwater potential zones,

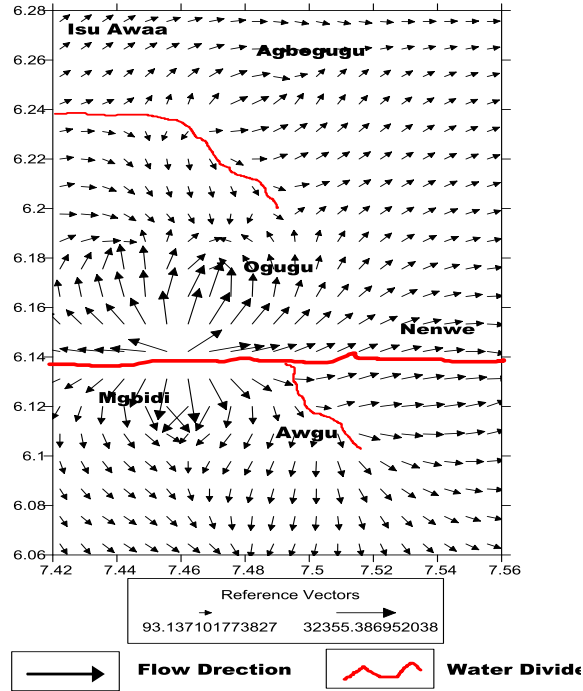

(b)

(b) Map of Groundwater Flow Directions 
Table 1: Interpreted Model Geoelectrical Parameters and Curve Types.
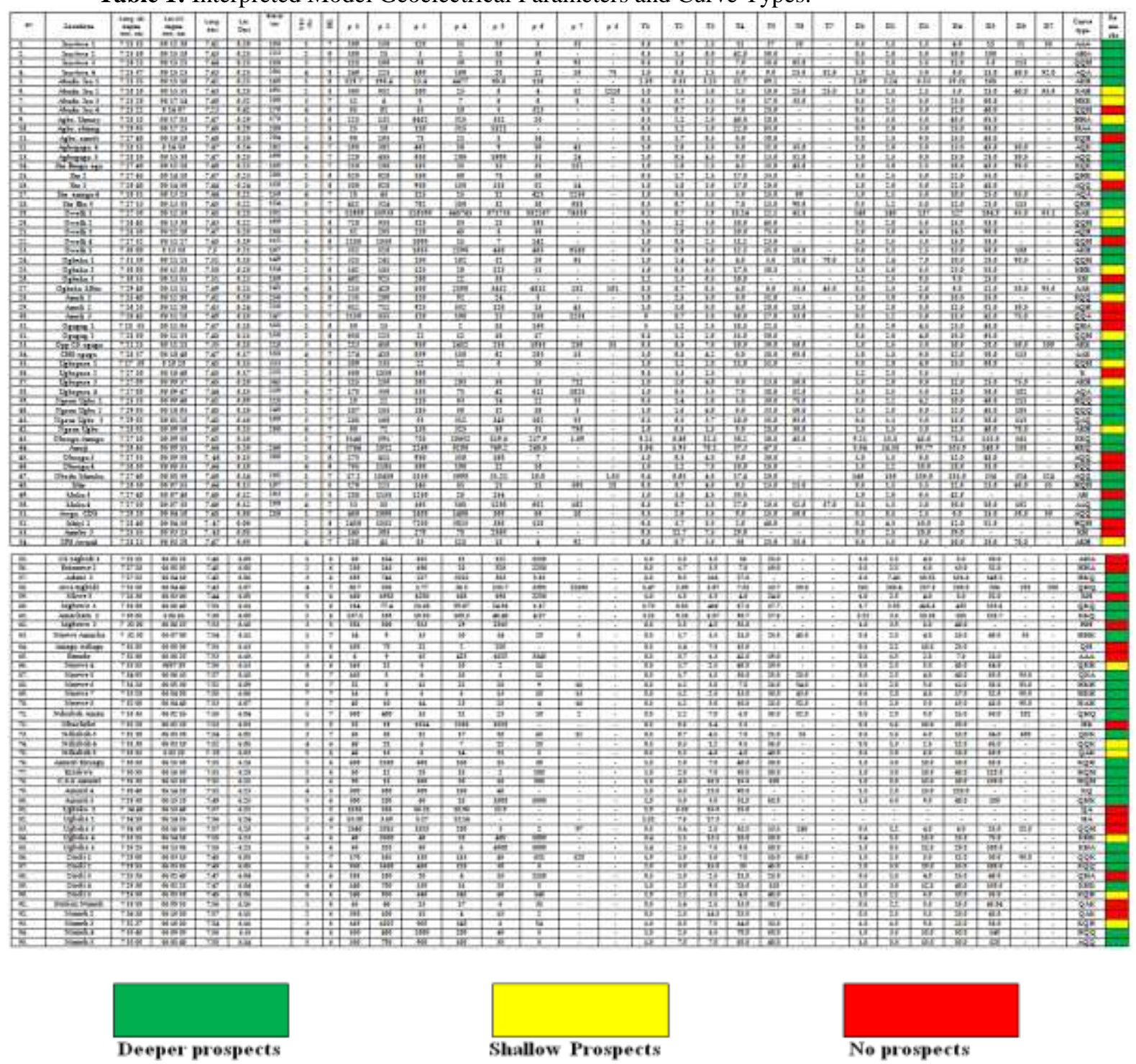

Table 2: Minimum-Maximum values of $\rho, T$ and $D$ of geoelectric layers

\begin{tabular}{|c|c|c|c|c|}
\hline NL & RESISTIVITIES, $\rho$ (Ohm-m) & THICKNESS, T(m) & DEPTH, D (m) & HORIZONS \\
\hline 1 & $6-11609$ & $0.2-6.09$ & $0.4-56$ & Top sandy layer \\
\hline 2 & $9-58938$ & $0.7-6.60$ & $1.5-115$ & Shale/ sand \\
\hline 3 & $15-6590$ & $3.5-32.8$ & $15-150$ & Shale/ sand \\
\hline 4 & $425-8745$ & $10-30.2$ & $25-170$ & Shale/ Clay \\
\hline 5 & $1025-7176$ & $27-36.8$ & $75-200$ & Shalely sand \\
\hline 6 & $3345-5000$ & $33-45.8$ & $30-250$ & Fractured Shale \\
\hline 7 & $8-4336$ & $37-70$ & $80-200$ & Fractured Shale \\
\hline 8 & $2-1126$ & - & - & - \\
\hline
\end{tabular}

\section{CONCLUSIONS}

Based on the study, the groundwater potential zones were delineated. About $50 \%$ of the study area falls within the deeper prospects ground water zones, $20 \%$ falls within shallow prospect groundwater potential zone, while the remaining $30 \%$ are areas where there is no prospect. The groundwater flow directions, Dar-zarrouk parameters, geology, and geoelectrical sounding attest to these facts. Hence, the groundwater potential rating of the area is considered generally moderate.

The results of this study have provided reliable information for borehole failure and abortive wells in the area, which was due to high content of argillaceous rock in the formation and the thin thickness of the layer. However there is evidence of deeper fractures. (Table 1) Future groundwater development in the study area should therefore; concentrate within the high/ medium groundwater prospect zones. Drill depth -deeper prospect 150-200meters, -shallow depth 50 - 60 meters 


\section{REFERENCE}

[1]. A. R. ZohdyApplication of surface geophysical (electrical methods to groundwater Investigations) techniques of water resources investigations of the United States Geological Survey. , (1976). 5-55.

[2]. A.C. Okonkwo, C. C. Ezeh, A.I, Opara., R.A.N. Nwatarali, M.S. Dimanyi, and E. Enang, Using the Dar- Zarrouk Concept to Infer the Subsurface Lithological Extent of Agbani Sandstone, Enugu State,Nigeria. International Research Journal of Geology and Mining (IRJGM) (2276-6618) Vol. 4(1) (2014) pp. 29-36,

[3]. B. C. Aneke, Water Resources of the Awgu Shale group, Enugu state, southeastern Nigeria. Unpub1. Ph.D Thesis, University of Nigeria, Nsukka. (2007).

[4]. C. C. Ezeh, Hydrogeophysical studies for the Delineation of potential Groundwater zones In Enugu State, Nigeria. Int. Res. J. Geol. Min. (2012). 2(5):103- 112

[5]. C. C. Ezeh, and, G. Z. Ugwu, Geolectrical sounding for estimating groundwater potential in Nsukka L.G.A. Enugu State, Nigeria. Int. J. Phys. Sci. (2010). 5(5):415- 420.

[6]. D. S. Paranis, Principles of Applied Geophysics 4th edition. Champman and Hall, NewYork, London., (1986).

[7]. E., Orellana, and H. M. Mooney, Master tables and curves for vertical electrical sounding over Layered structures. Interscience, Madrid. World Gazette 2011. Colourful map of Nigeria with 36 states (1966).. www.world-gazette.com

[8]. G. V. Kellar,, and F. C Frischknecht, Electrical methods in geophysical prospecting. Pergamon Press. (1966).

[9]. N. Sundararajan, Mansour Al-A- Garni, G. Rama Bramaham, and Y. Srinivas, Real spectral analysis of the deformation of electrical field. A Hartley transform approach Geophysics Prospecting. Vol 55, (2007). 901-910.

[10]. O. Koefoed, Geosounding principles, 1 Elsevier, Amsterdam (1979).

[11]. R. Maillet, The fundamental equations of electrical Prospecting. Geophysics 12:529- 556. (1947).

[12]. S, Niwas D.C Singhal Estimation of aquifer transmissivity from Dar-zarrouk parameters in porous media. J. Hydrol. (1981). 50:393-399.

[13]. R. A. Reyment, Aspects of the Geology of Nigeria. University of Ibadan Press. (1965). 133.

[14]. R. A. Reyment, "Review of Nigerian Cretaceous Cenozoic

[15]. Stratigraphy”. Journal Nigerian Mining Geological Metallurgical Society. (1964). 1:61-80. 